\title{
THE CERTAIN ISSUES OF THE ADMINISTRATIVE \\ AND LEGAL REGULATION OF THE ACTIVITY \\ OF THE NATIONAL POLICE OF UKRAINE
}

\section{Bondar Valeriia ${ }^{1}$}

DOI: http://dx.doi.org/10.30525/978-9934-571-29-9_1

Abstract. In the article the research of the specific problems of administrative and legal regulation of the activity of theNational police of Ukraine is conducted. The purpose of the scientific article is to carry out the analysis of certain problematic issues of the administrative and the legal regulation of the activity of the National Police of Ukraine. A scientific study of the administrative and legal regulation of the activity of the National Police was carried out in the works of V.M. Bevzenko, P.D. Bilenchuk, N.P. Bortnik, V.A. Glukhoveria, D.O. Denisyuk, S.S. Yesimov, V.V. Garbuzov, O.V. Kuzmenko, V.I. Kurilo, M.N. Kurko, D.M. Lastovich, I.V. Filshtein, A.A. Yarmoluk and others. However, today, the certain issues concerning the administrative and legal regulation of the activity of the National Police are of a scientific interest and require further research. In order to achieve the purpose of the scientific article, taking into account the object and the subject of the research, the general scientific and special methods were used in the article, in particular: dialectical method as a general method of scientific knowledge and historical and legal method allowed to consider all the issues of the topic in dynamics, to discover their interconnection and interdependence, to explore the ways of the developing of the legislation, that regulates the activity of the National Police of Ukraine, the comparative legal method, the logical-semantic method, the formal-logical method and the dogmatic (formal-legal) method. The recent research and publications on the subject is determined. The analysis of the legislation thatregulates the activity of the National Police of Ukraine is performed. The different approaches to understanding of the administrative and legalregulation are conducted. The definition of the administrative and legalregulation of the activity of the National police of Ukraine is provided. The analysis of the

\footnotetext{
${ }^{1}$ Candidate of Law Sciences, Associate Professor of Department of General Law and Social and Humanitarian Disciplines, Kherson Faculty of the Odessa State University of Internal Affairs, Ukraine

(C) Bondar Valeriia
} 


\section{Bondar Valeriia}

objectives and the principles of the activity of the National police of Ukraine is carried out. The analysis of the regulations not of the highest legal force is carried out too. In the article also the list of the legal acts that have been adopted by the time police work is provided. The research of the court practice and the lawyer practice is also given. It is concluded that the list of the valid legal acts that have been adopted by the time police work require reviewing and amending with current requirements, trends of the legal regulation and in order to bring them into line with the changes in the legislation and the adoption of the Law of Ukraine "About the National police". Some grounded recommendations for improving the Law of Ukraine "About the National police" are proposed. The author's version of the Article 40 of the Law of Ukraine "About the National police" is proposed.

\section{Introduction}

Formation of Ukraine as a legal, democratic and social state requires the providing of proper law and order, the achievement of which is impossible without the improvement of the legal framework that regulate the activity of the state authorities. First of all it concerns the activity of the bodies of internal affairs of Ukraine.

It should be noted that an important step in the reforming of the activity of the bodies of internal affairs of Ukraine aimed at raising of the level of law and order in the state, became the liquidation of the militia and the introduction of the National Police, that as correctly it is stated in the literature, from the tool of "force" support of the political regime should become a social institution, which guarantees the effective protection of the individuals, society and state from criminal encroachments [1].

As of today, the legislative basis of the newly created body is, firstly, insufficient, and secondly, it does not fully correspond to the realities of the present.

On July 2, 2015, the Verkhovna Rada of Ukraine adopted the Law of Ukraine № 580-VIII “About the National Police” (hereinafter - the Law). According to the Article 1 of the Law, the National Police of Ukraine is a central executive authority body that serves the society by the ensuring of the protection of human rights and freedoms, combating of crime, maintaining public security and order. In exercising of its powers, the police is guided by the following principles: the rule of law, the respect for human rights and freedoms, legality, openness and transparency, political 


\section{The certain issues of the administrative and legal regulation of the activity...}

neutrality, interaction with the population on the basis of the partnership, continuity.

At the same time, according to the Article 2 of the Law, police tasks are to provide police services in the following areas: 1) the ensuring of public safety and order; 2) the protection of human rights and freedoms, as well as the interests of society and the state; 3 ) combating and counteraction of crime; 4) provision of assistance services according to the law to persons who require such assistance because of personal, economic, social reasons or as a result of emergencies [2].

In addition, it is well-known that the successful exercise of the powers of any government body, including the National Police, and the compliance with its principles of activity, not least depends on the quality of legal acts that regulate its activity. It should be noted that certain inaccuracies, ambiguous interpretations, misunderstandings in the content of the legal acts, reduce their effectiveness.

Unfortunately, some rules of the Law are set out in such a way as to exclude the possibility of the effective administrative and legal regulation of the activity of the National Police, the ensuring of the compliance with the principles and implementation of the tasks of the latter.

Therefore, the issue of improving the legal acts that regulate the activity of the National Police, the bringing them in conformity with international standards is of high relevance.

\section{The concept of the administrative and legal regulation}

In addition, it should be noted that the legal regulation of the activity of public authorities is a significant place in the process of the building of Ukraine as a law-governed state. Therefore, it is obvious that the proper and effective execution of their functions and powers by the state authorities is impossible without the administrative and legal regulation, which requires further research and improvement.

At the same time, in the context of our study, the theoretical definition of the concept and content of the administrative and legal regulation of the activity of the National Police of Ukraine becomes relevant, for which it is first of all to apply to the doctrinal provisions of the administrative law.

Thus, in the theory of law under the legal regulation is understood as the purposeful influence of the legal norms that are adopted by the state and are the appropriate administrative means to ensure the rights and legitimate inter- 


\section{Bondar Valeriia}

ests of individuals and legal entities and the state in social relations in order to subordinate their legally established law and order, as well as with the protection and development in the interests of society and the state [3, p. 51].

In turn, in the legal encyclopedia the legal regulation is defined as the power of the state that is exercised by the state through all legal means to influence the social relations with a purpose to their ordering, consolidation, protection and development, as well as the influence on the behavior and consciousness of citizens through the declaration of their rights and responsibilities, the establishment of certain permissions and prohibitions, the approval of certain legal acts, etc. [4, p. 369].

At the same time, the administrative-legal regulation is understood as the purposeful influence of the norms of the administrative law on social relations in order to ensure the rights, freedoms and public legitimate interests of individuals and legal entities, the normal functioning of civil society and the state with the help of administrative and legal means.

Also the researchers-administrators distinguish the main features of the administrative-legal regulation: the purposeful nature, the presence of a certain subject and the scope of legal influence, the focus on the rights, freedoms and public interests of individuals and legal entities, organizational and orderly nature, the presence of certain stages that provide for the regulation of social relations, provision on the basis of the implementation of the administrative-legal method [5, p. 241-242].

There ia a similar view of T.S. Goncharuk, who considers the following: "Mechanism of the administrative-legal regulation - it is a system of the administrative and legal means (elements), through which the legal regulation (streamlining) of public relations in the field of public administration is carried out" $[6$, p. 23]. It should also be noted that taking into account the subject of the legal regulation of the administrative law, most scholars believe that the structure of the mechanism of the administrative-legal regulation consists of administrative-legal rules, acts of interpretation and acts of implementation of administrative-legal rules, administrative-legal relations.

It should also be noted that the vast majority of the blighty administrators and scholars point out that the subject of the legal regulation of the administrative law is social relations of managerial nature. At the same time, it should be emphasized that such leading administrators as V.K. Shkarupa and T.O. Kolomoets, rightly complement that the administrative law is intended 
to regulate relations in the sphere of the providing by the executive bodies and local self-government bodies of the implementation of the protection of rights, freedoms and legitimate interests of individuals and legal entities [7].

In the context of the study it should be noted that the above-mentioned scholars have developed a general doctrine of administrative law, formed by V.B. Averyanov, who believed that the basis of the new administrative-legal doctrine should be the human-centered ideology. According to it, the state should fully satisfy and defend the interests of citizens, that is, to act for the benefit of a man - through the comprehensive provision of the priority of his/her rights, the freedoms of legitimate interests in the field of public administration [8, p. 7].

Thus, taking into account the foregoing, we can conclude that the administrative and legal regulation is primarily intended to ensure the rights, freedoms and legitimate interests of a man and a citizen, as well as a society and the state as a whole.

\section{Law regulation of the activity of the National Police}

At the same time, it is necessary to note that in the scientific literature the analysis of the administrative and legal regulation of various state authorities, including the bodies of internal affairs, has been covered for quite some time.

Thus, the legal regulation of the bodies of the internal affairs is understood as the effective state influence on these bodies for the purpose of their organization in accordance with the tasks of society and the state in the interests of the protecting of human rights and citizens, which is ensured by a certain system of regulatory regulation $[9$, p. 45].

In this issue the opinion of D.V. Vlasenko is efficient. He claims that the administrative and legal regulation of the activity of the National Police should be considered as a process of streamlining by means of the administrative law, by authorized agents of the relevant social relations that arise in the connection with the organization and operation of the National Police [10, p. 126].

As we see, there are no significant differences between the abovementioned definitions of scientists regarding the administrative-legal regulation. All of them distinguish in the definition of the administrative law two obligatory elements: the power influence on social relations and the availability of certain legal means by which this influence is exercised. 


\section{Bondar Valeriia}

Thus, from the analysis of the above-mentioned definitions of the administrative-legal regulation, we can conclude that its mandatory element is the availability of the certain legal means, or rather, the administrative-legal norms through which the power influence on social relations is exercised.

The view of S.V. Kivalov is similar. He notes that the mandatory element of the mechanism of the administrative and legal regulation is administrative law rules as some rules of conduct, that are established or authorized by the state and are obligatory for implementation [11, p. 14].

At the same time, in the context of our study, it should be noted that the significance of the legal regulation is mediated by the object of such regulation, that is, the environment in which and under the influence of which law affects on social relations.

In this regard T. Takhovych claims that the sphere of the legal regulation is those social relations (economic, political, cultural, national, religious, etc.) that require legal influence. These relations that constitute the subject of legal regulation, are volitional, objectively need influence from the state and have a clearly defined content [12, p. 297].

Thus, taking into account the foregoing, in order to clarify the essence of the administrative and legal regulation of the activity of the National Police of Ukraine it is necessary to find out what should be understood under the notion of "the activity of the National Police of Ukraine", which is the subject of the said regulation.

At the same time, in order to determine the administrative and legal regulation of the activity of the National Police of Ukraine as an object of the administrative and legal regulation, it is necessary at first to reveal the content of such components of the concept as "the activity" and "the National Police of Ukraine".

It should be noted that the notion of the National Police of Ukraine is provided by the legislator in the Article 1 of Law of Ukraine № 580-VIII "About the National Police" and has already been mentioned earlier in our study. At the same time, it is necessary to apply to scientific literature to find out the meaning of the term "activity", which is an integral part of the concept "activity of the National Police of Ukraine".

So, according to the Academic Explanatory Dictionary of the Ukrainian language, activity means: 1. Application of one's work to something; 2. Functioning, action of organs of a living organism; 3. Detection of power, energy of something [13]. 


\section{The certain issues of the administrative and legal regulation of the activity...}

In the scientific literature, the category of "activity" is also defined in different ways, in particular: as the conscious actions of a person, that are accompanied by reflection; the process of the implementation of the norms in the field of labor relations [14]; as a process of creating by the subject of conditions for its existence and development or their using for transforming the environment in accordance with the goals and objectives of the organization in which it works [15, p. 234]; as a manifestation of the abilities of the individual during the practical using of his intellectual capital for the purposeful change of certain economic and social objects [16, p. 83]. In this case, the activity is connected with the activity of the person (subject). It is the internal (psychic) and external (physical) activity of the person (subject), that is regulated by the realized purpose [17, p. 43], is the basis of the activity, its essence.

Thus, we can conclude that the category of "activity" is disclosed primarily because of the term "actions", that is why the activity of the National Police of Ukraine from the legal point of view can be considered through a set of the legal acts that are carried out by certain subjects.

Taking into account all the above and the fact that the content of the administrative-legal regulation is characterized by the presence of a specific imperative-power method, in order to clarify the content of the administrative and legal regulation of the activity of the National police of Ukraine as the object of the administrative and legal regulation it is necessary to to uncover its features.

So, the analysis of the legislation and the scientific literature allows us to state that the features of the administrative and legal regulation of the activity of the National police of Ukraine are:

- the administrative and legal regulation of the activity of the National police of Ukraine has a purposeful character, because such regulation is directed at the regulation of certain social relations, namely those that arise from the activity of the National Police of Ukraine;

- the administrative and legal regulation of the activity of the National police of Ukraine is aimed primarily at ensuring constitutional rights, freedoms and public interests of a person and a citizen;

- the administrative and legal regulation of the activity of the National police of Ukraine is carried out on the basis of norms of administrative law;

- the administrative and legal regulation of the activity of the National police of Ukraine is carried out with the help of the means and methods of 


\section{Bondar Valeriia}

the administrative-legal regulation, which are used by the subjects of the public administration in the field of the administrative and legal regulation of the activity of the National Police of Ukraine;

- the administrative and legal regulation of the activity of the National police of Ukraine is accompanied by the emergence of the subjective public rights and obligations among the subjects of legal relations that arise in the course of the activity of the National Police of Ukraine.

Thus, we can state that under the administrative legal regulation of the activity of the National Police it is necessary to understand the system of the administrative and legal means that are used by the subjects of the public administration, which within their competence are called to regulate the activity of the National Police on the basis of the administrative law norms, that are aimed at the exercise of influence on social relations in order to ensure the constitutional rights and legitimate interests of man and citizen.

Consequently, taking into account the foregoing, in order to identify the problematic issues in the administrative and legal regulation of the activity of the National Police, it is necessary to analyze some of the administrative and legal norms governing the activity of the latter.

\section{The problems of the legislative support of police activity}

Problems of the legislative provision of police activity can be considered from the point of view of the existence of the legal basis of the police activity and the availability of gaps and collisions in certain legal acts.

So, speaking about the normative acts that concern the activity of the police itself, it should be noted that there are not many normative acts at the moment.

The main legal acts that regulate the activity of the police are the Law of Ukraine "About the National police" from 2 July, 2015 № 580-VIII, the Posture about the National Police, approved by the Resolution of the Cabinet of Ministers of Ukraine from 28 October, 2015 № 877, the Posture about the patrol service of the Ministry of the Internal Affairs, approved by the Order of the Ministry of the Internal Affairs of Ukraine dated 02.07.2015 № 796, the Resolution of the Cabinet of the Ministers of Ukraine dated September 30, 2015, № 823 “About the Uniformity of the Police”, the Instruction of the registration of the police materials on administrative violations in the field of the road safety, recorded not in the automatic mode, approved by the Order of the Ministry of the Internal Affairs of Ukraine of 07.11.2015 № 1395, the 
Instruction about the procedure of detecting of the drivers of vehicles of signs of alcohol, narcotic or other intoxication or staying under the influence of drugs that reduce the attention and the speed of reaction, approved by the joint Order of the Ministry of the Internal Affairs of Ukraine and the Ministry of Health of Ukraine from 09.11.2015 № 1452/735, the Resolution of the Cabinet of the Ministers of Ukraine dated 17.12.2008 № 1103 “About the approval of the Procedure of the referral of drivers of vehicles for inspection to detect the condition of alcohol, drugs or other drunkenness or stay under the influence of medicinal products that reduce the attention and speed of reaction, and the conduct of such review", the Order of the Ministry of the Internal Affairs of Ukraine dated 23.12.2015 № 1614 "About the organization of the issuing of special tokens by the police".

Along with this, the National Police is guided in its activities by normative acts that were adopted during the operation of the militia and regulated its activity, that adversely affects to the activity of the police today.

These acts include the Law of Ukraine of June 30, 1993, №. 3353-XII "About the Road Traffic", the Order of the Ministry of the Internal Affairs of Ukraine dated December 19, 2012 № 1176 "About the Approval of the Instruction of the organization of the work of the criminal department militia of children's affairs, the Disciplinary Statute of the internal affairs institutions of Ukraine from 22.02.2006 № 3460-IV, the Resolution of the Cabinet of the Ministers of Ukraine of 10.10.2001 № 1306 “About the Rules of the Road", a letter of the Ministry of the Internal Affairs of Ukraine dated November 25, 2009 № K-4836, etc.

It should be noted that this is not an exhaustive list of the normative legal acts that are referenced by the staff of the National Police in carrying out their activity, however, the said legal acts regulate the procedure for the activity of the officers of militia. In accordance with paragraph 5 of the Section XI of the Law "The final and transitional provisions" of the Law of Ukraine "About the Militia" was declared invalid. Therefore, the reference to these acts is illegal, because in accordance with the Article 19 of the Constitution of Ukraine, bodies of state power and bodies of local self-government, their officials are obliged to act only on the basis, within the limits of authority and in the manner that is provided by the Constitution of Ukraine and the laws of Ukraine.

The National Police is a state authority and, accordingly, its discretionary powers and the manner in which they are carried out should be exclusively 


\section{Bondar Valeriia}

within the principle of lawfulness, with the application of the norms that are legally valid during the process of the bringing to the legal liability of the legal entities and the individuals. Failure to adhere to this principle leads to the negative consequences in the form of the destruction of the legal basis for the functioning of the mechanism of state authorities, as separate units.

Consequently, taking into account the foregoing, we can conclude that the normative acts that were adopted during the operation of the militia in order to regulate the activity of the latter, which are still in force, need to be revised and amended to take into account modern requirements, trends of legal regulation and in order to bring them in line with changes in the legislation and the adoption of the Law of Ukraine "About the National Police".

\section{The problems of legal regulation of the activity of the National Police}

In the context of our study it should also be noted that in the area of the administrative and legal regulation of the activity of the National Police there are still some problematic issues.

Thus, the Article 40 of the Law of Ukraine "About the National Police" contains provisions that the police may, for the purpose of the ensuring of public safety and order in order to prevent, detect or record offenses, protect public safety and property, ensure the safety of persons and ensure the observance of traffic rules, may fix to uniforms, office transport facilities, mount / place on the external perimeter of roads and buildings automatic photo and video equipment, and also use information that was obtained from automatic photo and video equipment that residing in someone else's possession [2].

The said right derives from the provisions of the Article 9 of the Law of Ukraine "About the National Police", which stipulates that the police is acting on the principles of openness and transparency.

As we see, the norm that is analized in the study is not imperative, since it does not oblige the National Police staff of Ukraine to use with their powers technical devices and technical means that have photography and motion pictures functions, video recording, or photo means in each case when staff is exercising their authority.

We believe that the wording of the article 40 of the Law of Ukraine "About the National Police" in this version does not contribute to the achievement of the objectives of the police, the effective implementation 
of the police officers of their powers, as well as the protection of the police themselves.

This is primarily due to the fact that one of the aspects of the implementation of the tasks of the National Police of Ukraine is the proceedings in cases of the administrative offenses that are committed by the police officers of Ukraine in order to timely, comprehensively, fully and objectively clarify the circumstances of each case, resolve it in strict accordance with the law, the ensuring of the implementation of the issued resolution, as well as the identifying of the causes and the conditions that conducive to the administrative offenses, the preventing of the offenses, the educating of the citizens in the spirit of the observance of laws, and strengthening the rule of law.

The administrative offense (misdemeanor) is meaned as the unlawful, guilty (intentional or negligent) act or inaction that infringes to public order, property, rights and freedoms of citizens, to the established procedure of management and for which the law provides for the administrative liability (the Article 9 of the Code about Administrative Offenses) and therefore the proof of the guilt is one of the circumstances to be proved in cases of administrative offenses.

Yes, according to the Article 280 of the Code of Ukraine About the Administrative Offenses the body (the official), including the staff of the National Police during the considering a case about an administrative offense, are obliged to find out: whether an administrative offense was committed, whether this person is guilty of his commission, whether it is subject to administrative responsibility, whether there are the circumstances mitigating and aggravating the responsibility, whether material damage was caused, whether there are grounds for the transfer of material about an administrative offense to the consideration of a public organization, a labor collective, as well as to find out other circumstances that have a meaning for the proper resolution of the case [18].

In addition, in the process of the proceedings about administrative offenses that is committed by the National Police officers, the latter apply a variety of measures to secure proceedings in cases of administrative offenses: administrative detention, personal review and review of the things, seizure of the things and documents, temporary withdrawal of a driver's license, temporary detention of vehicles, removal of persons from the management of vehicles, river and small size vehicles and inspection 


\section{Bondar Valeriia}

of the state of alcohol, narcotic or other intoxication, or due to exposure to medicines that reduce their attention and reaction rate.

The above circumstances, as well as the legality of the application of measures to ensure the conduct of cases about the administrative offenses are established by means of evidence.

According to the Article 251 of the Code of Ukraine about administrative offenses the evidence in an administrative offense case is any factual data on the basis of which the authority (the official) determines in the statutory procedure the presence or absence of an administrative offense, the guilt of the person in his commission and other circumstances of the importance for the correct solution to a case [18].

These data are established by the protocol about the administrative offense, by the explanations of the person who is being brought to the administrative liability, victims, witnesses, the expert opinion, the material evidence, the testimonies of the technical devices and technical means, which have functions of photo and video shooting, video recording, including those that are used by the person who is the subject of the administrative liability, or witnesses, and also those/which who are working in an automatic mode, or means of photographing and filming, video recording, including those that are used by the person who is the subject of the administrative liability, or witnesses, and also those/which who are working in an automatic mode, which are used when the supervising for the observance of the rules, norms and standards concerning road traffic safety, by the protocol on the removal of things and documents, as well as other documents.

It should be noted that the duty to collect the evidence relies on the persons that are authorized to compile the protocols about the administrative offenses, that are determined in the Article 255 of the Code of Ukraine about administrative offenses.

At the same time, the body (the official) evaluates the evidence based on its internal conviction, based on a comprehensive, complete and objective study of all the circumstances of the case in their totality, guided by the law and legal awareness [18].

In addition, it should also be noted that the analysis of the judicial practice allows us to state that the legality of measures of the ensuring of the proceeding of the cases in administrative offenses, as well as the imposition of administrative penalties at the place of committing of the administrative offense or in court is often contested in the court. 


\section{The certain issues of the administrative and legal regulation of the activity...}

Therefore, the presence of photographic and filming, video recording at the judicial appeal of the decisions of competent bodies to bring to the administrative liability and to apply some measures to ensure the conduct of cases about administrative offenses, would be crucial.

In our view, in order to ensure the rule of law, security and law order, the protection of human rights and freedoms, the interests of society and the state, as well as the fight against crime, it is necessary to oblige the employees of the National Police of Ukraine to use technical devices and technical means in each case, when they are exercising their authority, that have the functions of photography and film, video recording, or photographic and cinematographic, video recording.

Thus, in order to improve the administrative legislation and to eliminate existing legislative gaps, we propose the part 1 of the Article 40 of the Law of Ukraine "About National Police" to spell out in such edition:

The Part 1 The police to ensure public security and order with a purpose of:

1) prevention, detection or recording of an offense;

2) protection of public safety and property;

3) security of persons and their own security;

4) ensuring of compliance with the rules of the road:

- is obliged to fix on the uniform clothes, the service vehicles, the automatic photo and video equipment, and also to use the information received from the automatic photo and video equipment, which is in someone else's possession;

- has the right to mount / place on the external perimeter of the roads and buildings automatic photo and video equipment.

The Part 2 The information about mounted / placed automatic photographic equipment and video equipment must be placed in a prominent place.

3. The persons must be notified by a police officer of the using of the automatic photo and video equipment.

\section{Conclusions}

Summing up the above, we can conclude the following:

1) the administrative and legal regulation is primarily intended to ensure the rights, freedoms and legitimate interests of a man and a citizen, as well as a society and the state as a whole;

2) the administrative legal regulation of the activity of the National Police it is necessary to understand the system of the administrative and 


\section{Bondar Valeriia}

legal means that are used by the subjects of the public administration, which within their competence are called to regulate the activity of the National Police on the basis of the administrative law norms, that are aimed at the exercise of influence on social relations in order to ensure the constitutional rights and legitimate interests of man and citizen;

3 ) the normative acts that were adopted during the operation of the militia in order to regulate the activity of the latter, which are still in force, need to be revised and amended to take into account modern requirements, trends of legal regulation and in order to bring them in line with changes in the legislation and the adoption of the Law of Ukraine "About the National Police".

4) the Law of Ukraine "About the National Police" requires the improvement in the term of consolidation of the imperative law rules that relate the using of technical equipment and equipment by employees of the National Police with functions of photography and motion pictures, video recording, or photographic and cinematographic, video recording.

\section{References:}

1. Lipkan V.A. (2007) Problemi i shlyahi udoskonalennya pravovogo zabezpechennya upravlinnya $\mathrm{v}$ organah vnutrishnih sprav [The problems and ways of improving the legal support of the governance in the internal affairs bodies]. - [Electronic resource]. Teoriya upravlinnya $\mathrm{v}$ organah vnutrishnih sprav (electronic textbook). Available at: http://semestr.com.ua/book 378 glava_155_3.\%C2\%A0\%C2\%A0\%C2\%A0\%C2\%A0_Problemi_\%D1\%96_shljakh. html (accessed 10 March 2018).

2. The Law of Ukraine dated July 2, 2015 № 580-VIII “About the National Police" [Electronic resource]. Available at: http://zakon2.rada.gov.ua/laws/show/58019/ page?text $=\% \mathrm{EF} \% \mathrm{~F} 0 \% \mathrm{E} 0 \% \mathrm{E} 2 \% \mathrm{EE} \% \mathrm{ED} \% \mathrm{E} 0$ (accessed 10 March 2018 ).

3. Terymetsky V. I. (2012) Ponyattya administrativno-pravovogo regulyuvannya u sferi opodatkuvannya [The concept of the administrative-legal regulation in the field of taxation]. State and regions. The set "Law", vol. 1, 35, pp. 50-54.

4. Gizhevsky V.K., Golovchenko V.V., Kovalsky V.S. (2002) Populyarna yuridichna enciklopediya [The Popular Law Encyclopedia]. Kyiv: Yurincom Inter.

5. Galunko V.V., Olefir V.I., Pikhtin M.P. (2011) Administrativne pravo Ukraïni : navchal'nij posibnik u 2-h tomah [The administrative law of Ukraine: a textbook in 2 volumes]. Kherson: HMT.

6. Goncharuk S.T. (2000) Administrativne pravo Ukraïni. Zagal'na ta Osobliva chastini : na- vch. posib. na dopomogu sluhacham, shcho zdayut' derzh. ta potochni ispiti z adm. prava [The Administrative Law of Ukraine. General and Special Parts: tutorial to help students handing over the state and current exams with admins. Law]. Kyiv: Nat. acad. Of Internal Affairs; National acad. of Supervision. 


\section{The certain issues of the administrative and legal regulation of the activity...}

7. Shkarupa V.K., Kolomoets T.O., Gulevskaya G.Y. (2007) Administrativne pravo Ukraïni : navchal'nij posibnik [The Administrative Law of Ukraine: textbook]. Kyiv: Truth.

8. Averyanov V.B., Derets V.A., Shkolik A.M. (2007) Publichne upravlinnya: €vropejs'ki standarti, dosvid ta administrativne pravo [The Public administration: European standards, experience and administrative law]. Kyiv: Justinian.

9. Petrova I.P. (2004) Normativno-pravove regulyuvannya organizaciï i diyal'nosti miliciï Ukraïni [The normative and legal regulation of the organization and activity of the militia of Ukraine] (PhD Thesis), Irpen: National Academy of State Tax Service of Ukraine.

10. Vlasenko D.V. (2016) Suchasnij stan administrativno-pravovogo regulyuvannya diyal'nosti Nacional'noï policiï Ukraïni [Modern state of the administrative-legal regulation of the activity of the National Police of Ukraine]. Law and Society, vol. 4, 2, pp. 125-130.

11. Kivalov S.V. (2013) Administrativne pravo Ukraïni : uchebnik [The Administrative law of Ukraine: textbook]. Odessa : Yurid. 1-ra.

12. Zaychuk O.V., Zayets A.P., Zhuravsky V.S. (2006) Teoriya derzhavi i prava. Akademichnij kurs [The Theory of state and law. Academic course]. Kyiv:Yurinkom Inter.

13. The Dictionary of the Ukrainian language. Academic Explanatory Dictionary (1970-1980) [Electronic resource]. Available at: http://sum.in.ua/s/dijaljnistj.

14. Kolpakov V. K. (2002) Yak prijmati rishennya? [How do we make decisions?]. Staff, vol. 8, pp. 54-61.

15. Belyavsky N.P., Veselko S.E., Roish P. (2006) Upravlinnya personalom: navchal. posibnik [Personnel Management: Study. Allowance]. Minsk: IP "Ecoperspectiva".

16. Khokhlov B. (2005) Naemnye rabotniki i korporativnoe upravlenie [Employers and corporate management]. Man and labor, vol. 33, pp. 82-83.

17. Yesinova N.I. (2003) Ekonomika truda i social'no-trudovye otnosheniya: Ucheb. Posobie [The Economics of Labor and Social-Labor Relations: Textbook]. Kyiv: Kondar.

18. The Code of Ukraine about Administrative Offenses dated December 07, 1984 № 8073-X [Electronic resource]. Available at: http://zakon2.rada.gov.ua/laws/ show/80731-10/paran3896\#n3896 (accessed 10 March 2018). 